\title{
Herpes simplex keratitis: challenges in diagnosis and clinical management
}

This article was published in the following Dove Press journal:

Clinical Ophthalmology

19 January 2017

Number of times this article has been viewed

\author{
Tayaba N Azher' \\ Xiao-Tang Yin' \\ Deena Tajfirouz' \\ Andrew JW Huang ${ }^{2}$ \\ Patrick M Stuart' \\ 'Department of Ophthalmology, Saint \\ Louis University, ${ }^{2}$ Department of \\ Ophthalmology and Visual Sciences, \\ Washington University, St Louis, \\ MO, USA
}

\begin{abstract}
Herpes simplex virus is responsible for numerous ocular diseases, the most common of which is herpetic stromal keratitis. This is a recurrent infection of the cornea that typically begins with a subclinical infection of the cornea that establishes a latent infection of sensory ganglia, most often the trigeminal ganglia. Recurring infections occur when the virus is reactivated from latency and travels back to the cornea, where it restimulates an inflammatory response. This inflammatory response can lead to decreased corneal sensation, scarring, and blindness. The diagnosis of these lesions as the result of a recurrent herpes simplex virus infection can at times be problematic. Currently, herpetic stromal keratitis is diagnosed by its clinical presentation on the slit-lamp examination, but the literature does not always support the accuracy of these clinical findings. Other diagnostic tests such as polymerase chain reaction assay, enzyme-linked immunosorbent assay, immunofluorescent antibody, and viral cultures have provided more definitive diagnosis, but also have some limitations. That said, accurate diagnosis is necessary for proper treatment, in order to prevent serious consequences. Current treatment reduces the severity of lesions and controls further viral spread, but does not provide a cure.
\end{abstract}

Keywords: herpes simplex virus, herpetic stromal keratitis, cornea

\section{Introduction}

Herpes simplex virus (HSV) is a ubiquitous DNA virus that can infect virtually anywhere in the body, particularly when newborns are infected. ${ }^{1-3}$ However, in an individual with a normal immune system, the most common sites of infection are the mouth, genitalia, and eyes. In very young children, and in rare instances adults, the brain may also become infected. HSV infections of the eye are the leading cause of infectious corneal blindness in developed countries. ${ }^{4}$ Approximately 500,000 people in the US are currently infected with ocular HSV. ${ }^{5,6}$ The costs of treatment for this disease are in the tens of millions spent annually in the US alone. ${ }^{6}$ While most infections are unilateral, around $1.3 \%-12 \%$ of affected individuals have bilateral ocular infections. Bilateral infections are seen mostly in immunocompromised patients. ${ }^{7-9}$ Infections can occur in both anterior and posterior segments of the eye, but it most commonly infects the corneal epithelia., ${ }^{4,8}$ It is primarily diagnosed by its clinical presentation, but atypical presentation of the infection can impede accurate diagnoses and thus proper treatment. ${ }^{10}$

\section{Pathophysiology}

$\mathrm{HSV}$ is a linear double-stranded DNA virus that is classified as an $\alpha$-member of the Herpesviridae family. ${ }^{5,11}$ Primary infection results after HSV spread via direct contact with mucous membrane of the host. ${ }^{5,11}$ In the case of ocular infections, the virus 
is transported following primary retrograde infection via sensory neurons to establish latency in trigeminal ganglia; here, it remains asymptomatic until reactivation of the virus leads to secondary or recurrent infections. ${ }^{4,8,12,13}$ The host cell's DNA polymerase, located in the nucleus of the cell, is required for HSV to transcribe and replicate. . $^{814}$
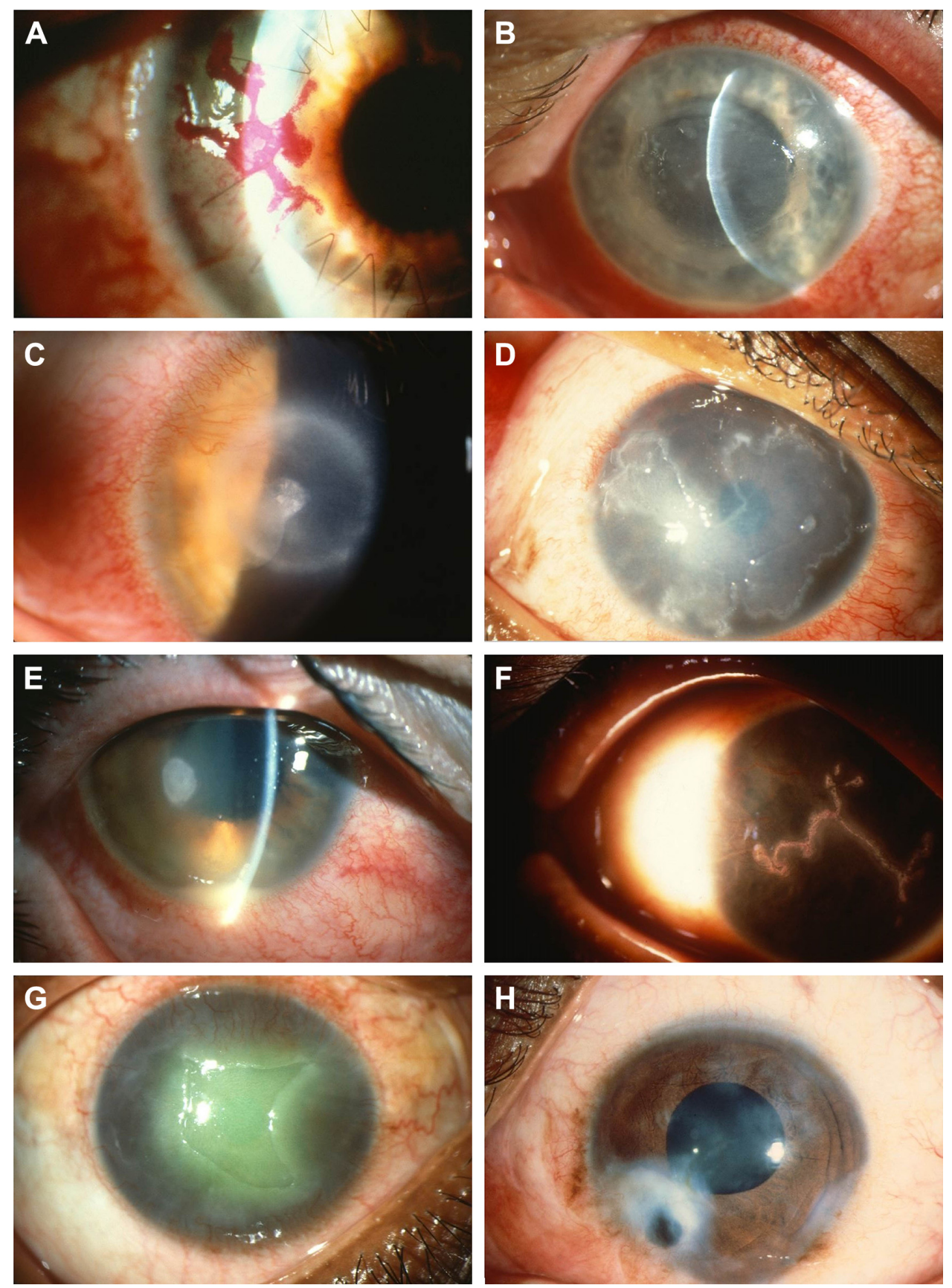

Figure I Representative images of various corneal damages due to HSVI infection.

Notes: (A) Large herpetic epithelial dendrite at graft-host junction. (B) Large subepithelial bulla due to HSV endotheliitis. (C) Ring-lipid deposit surrounding a focal HSV disciform keratitis. (D) Large geographic herpetic ulcer in HIV patient. (E) Herpetic keratouveitis with anterior chamber inflammation (layered hypopyon due to WBC accumulation), small keratic precipitates (WBC aggregates on the corneal endothelial surface), and corneal edema (due to endothelial dysfunction). (F) Large herpetic epithelial dendrite. (G) Postherpetic neurotrophic epithelial defect due to corneal nerve damage by HSVI. (H) Large herpetic corneal scar with iris incarceration to the side of corneal perforation.

Abbreviations: HSV, herpes simplex virus; WBC, white blood cell. 
response to the virus. The stromal subtype can be further divided into disciform keratitis, immune SK, and necrotizing keratitis. Endothelial keratitis manifests as rejection line-like keratic precipitates and stromal edema. Variation in presentation between different subtypes has posed a challenge in accurately diagnosing this condition. ${ }^{15}$

\section{Diagnosis}

HSK is primarily diagnosed by its clinical presentation on the slit-lamp examination. ${ }^{4}$ Common symptoms include redness, discharge, watery eyes, irritation, itching, pain, and photophobia. In most patients, symptoms begin to subside after the first 2 weeks. ${ }^{4}$ The most common subtype, epithelial keratitis, appears as coarse granular spots that form punctuate lesions, but these quickly coalesce to form dendritic lesions. ${ }^{16-18}$ A physical examination may reveal whitened area. ${ }^{19}$ On the slit-lamp examination, epithelial keratitis presents as a dendritic lesion with a terminal bulb, swollen borders, and intraepithelial cell infiltration. ${ }^{15}$ It is visualized by staining the lesion with either lissamine green or rose bengal dye. ${ }^{20}$ For atypical epithelial lesions, polymerase chain reaction (PCR) has been used to confirm HSK. ${ }^{21}$ Newer methods, such as tear collection and immunofluorescence antibody assay (IFA), have also been employed to aid identification of epithelial lesions. ${ }^{22,23} \mathrm{SK}$ on physical examination appears opaque or whitened, due to stromal infiltration. ${ }^{20,24}$ Similarly, the necrotizing form of SK appears as gray-white or opaque, but there is accompanying necrosis and ulceration on slit-lamp examination. ${ }^{20,24}$ Edema and abscess may be apparent as well. ${ }^{4,25}$ In immunomediated SK, necrosis or ulceration is lacking, but there is stromal infiltration. ${ }^{26}$ Unfortunately, PCR has been less helpful for identification of immunomediated SK. Another form of HSK, disciform lesion, has a ground-glass appearance and is disk shaped with stromal edema on slit-lamp examination. ${ }^{27}$ Lastly, the endothelial form, keratic precipitates, and iritis may be visible. Stromal edema is also present. ${ }^{27}$ Enzymelinked immunosorbent assay (ELISA) and viral cultures have been used as diagnostic tools for all subgroups of lesions. ${ }^{15,28}$ Dendritiform epithelial lesions on slit-lamp examination are pathognomonic for keratitis. However, atypical lesions can make diagnosis difficult. ${ }^{15}$ Factors affecting diagnosis include duration of illness, systemic diseases, previous medication use, and corneal transplantation, as these can change the appearances of lesions on slit-lamp examination. ${ }^{21}$

Misdiagnosis in clinical settings is not uncommon, as other pathogens can present with similar lesions. ${ }^{10}$ Amebic and fungal infections have been mistakenly identified as
HSV keratitis. ${ }^{13}$ In a study conducted by Rübben et al, 8\% of the clinically diagnosed HSV lesions were identified on PCR assay as lesions caused by another member of the Herpesviridae family - varicella zoster virus. ${ }^{29}$ Similarly, another study uncovered $5 \%$ of clinically diagnosed HSK lesions as lesions caused by adenovirus, 3.2\% as lesions caused by cytomegalovirus, and $2.7 \%$ by enterovirus. ${ }^{30}$ When PCR was used to confirm clinical diagnosis of epithelial dendritiform lesions, there was only moderate correlation ( $K=0.485, P<0.0001)$ between diagnosis made by an ophthalmologist and diagnosis made using PCR. ${ }^{10}$ In a study designed to address the diagnosis of atypical HSK lesions, Koizumi et al defined atypical lesions as those where "dendritic or geographical ulcers with terminal bulbs and epithelial infiltrations are not evident". They found very little agreement $(P=0.22)$ between PCR results and clinical diagnosis. $^{21}$

While most diagnoses of HSK are based on clinical presentation, PCR provides better sensitivity. In a study conducted by El-Aal et al, PCR detected 29.2\% more cases than cell culture. ${ }^{22}$ In another study, while viral culture identified $12 \%$ of suspected patients with HSK, PCR identified $88 \%$ of suspected patients. ${ }^{22}$ PCR is highly sensitive, but large variation has been observed in various studies between the rate of HSV detection by PCR when compared to clinical diagnosis. ${ }^{10}$ PCR is more likely to identify patients that present with typical lesions or patients who have not used antiviral medications $(P=0.022)$. It is less responsive in patients with atypical lesions or in patients who previously used or currently use antiviral medications $(P=0.968) .{ }^{28}$ It has been hypothesized by McGilligan et al that because $\mathrm{SK}$ is a result of immune response to the virus, rather than the viral infection itself, it may explain the negative PCR results. Variation was also seen (4\%-6\% variability) when the same samples were reanalyzed using different amplification regions of the gene. ${ }^{10}$ In another study, there was an $80 \%$ decrease of detectable virus in patients who had been taking $400 \mathrm{mg}$ of acyclovir twice daily. ${ }^{31}$ This can lead to reduction in PCR sensitivity. ${ }^{13}$ PCR-based tests can also result in false negatives. ${ }^{31,32}$

Similarly, ophthalmologists use oxybuprocaine, a local anesthetic that is used in conjunction with fluorescein-based dye to visualize possible HSV corneal lesions better, but can decrease the effectiveness of PCR by interfering with the PCR reaction, resulting in a decrease of more than 2 logs (DNA copies/sample). ${ }^{33}$ Other dyes, such as rose bengal and lissamine green, also inhibit the detection of HSV DNA by PCR assay. ${ }^{34}$ 
PCR assays require corneal scrapings. Unfortunately, patients with recurrent infections may have decreased corneal thickness, thus restricting the ophthalmologist from performing corneal scraping to obtain a specimen. ${ }^{23}$ Alternatively, viral load can be determined from patient tears. ${ }^{23}$ Satpathy et al compared viruses collected by this less invasive technique with that collected by corneal scraping using immunofluorescence assay, PCR, and viral titering. ${ }^{23}$ The results indicated that immunofluorescence assay detected viral antigen in $12.53 \%$ of tear specimens and $22.87 \%$ of corneal scrapings, PCR detected the virus in $13.97 \%$ of tear specimens and $36.66 \%$ of corneal scrapings. Lastly, infectious virus was detected from $5.2 \%$ of tears and $11.11 \%$ of corneal scrapings. While PCR of virus collected from tears was more sensitive than both viral isolation and immunofluorescence from tears, it was significantly less sensitive than corneal scrapings $(P<0.0005) .{ }^{23}$ Once again, the timing of testing tear film is a concern, as the virus rarely persists as long as the corneal lesions do. ${ }^{23}$

Along with PCR, ELISA has also been used to detect virus in tear collections. Shoji et al measured HSV DNA using real-time PCR and measured HSV-specific secretory immunoglobulin A (IgA) antibody using ELISA in tears of clinically suspected HSK patients. ${ }^{15}$ Overall, sensitivity of ELISA was 49.2\% and specificity $82.6 \%$. On the other hand, sensitivity and specificity for real-time PCR were higher at $55.8 \%$ and $100 \%$, respectively, in tears collected. However, when divided into subgroups, real-time PCR detected HSV DNA levels in the disciform keratitis subgroup (median $3.1 \times 10^{2}$ copies/sample), significantly less than it detected HSV DNA in the dendritic/geographic keratitis subgroup (median $2.3 \times 10^{4}$ copies/ sample) $(P<0.05$, Mann-Whitney test). Detection of HSV DNA was also low in the atypical subgroup. ${ }^{15}$ Furthermore, viral load in tears decreased after day 11 of illness which could have further increased false negatives in all subgroups. ${ }^{15}$

Viral culture is considered the gold standard for identifying HSV. ${ }^{28}$ When compared to viral culture, clinical diagnosis is only $55 \%-65 \%$ accurate. ${ }^{28}$ Unfortunately, culturing HSV is time-consuming and can take a week or longer when few infectious viruses are in the sample, and typically underestimates the number of patients whose disease is due to HSV. ${ }^{23,35}$ IFA has also been used to diagnose HSV and detects $33.3 \%$ more positive cases than viral culture. It also had sensitivity of $80 \%$, specificity of $71.4 \%$, positive predictive value of $63.6 \%$, and negative predictive value of $81.8 \%$. In other studies, the sensitivity of IFA in diagnosing HSV ranged from $77 \%$ to $86 \%{ }^{22}$ However, sample size and false-positive and falsenegative results can unfavorably influence IFA. ${ }^{23}$
HSK is a leading cause of corneal blindness. ${ }^{4}$ Accurate and prompt diagnosis is necessary to start the proper treatment and prevent further complications. Variation in different subtypes has posed a challenge to accurately diagnose HSK. ${ }^{15}$ This has also prevented a unified or specific test from properly diagnosing all of the different subtypes in a quick and effective manner.

\section{Challenges to clinical management}

Most infections of HSK are self-limiting, even without treatment. However, healing is prolonged without the use of proper medication, and inappropriate treatment can worsen corneal inflammation and lead to recurring lesions and vision loss. On the other hand, other subtypes, such as geographic epithelial keratitis, are difficult to treat and require prolonged therapy. ${ }^{13}$ Although episodes can be self-limiting, it is essential to treat the infection at the earliest onset to reduce viral replication, shorten disease course, and maintain latency, in order to prevent further complications.

Current treatment for HSK includes acyclovir, ganciclovir, triflurothymidine, penciclovir, and valacyclovir. ${ }^{13,36}$ Acyclovir and its derivatives are nucleoside analogs that are selectively phosphorylated by the virally encoded thymidine kinase to be used as a substrate by DNA polymerase; this drug is not a substrate for the host thymidine kinase, and thus has a reduced side-effect profile. Once the analog is phosphorylated, it is incorporated into the viral DNA as it is being synthesized. Since this analog does not possess the chemical structure for subsequent nucleosides to be added, this results in chain termination and prevents viral replication by inhibiting DNA elongation..$^{8,37,38}$ Because it affects only newly synthesized viral DNA, it does not cure infected cells of the virus, but it does prevent new viruses from being produced. Since acyclovir has poor bioavailability, high doses and increased frequency of administration are required. ${ }^{8,36,39,40}$ Valacyclovir, another nucleoside analog, has improved bioavailability, and thus it has reduced frequency of administration and can lead to better patient adherence. ${ }^{41}$ Both acyclovir and valacyclovir can cause nausea, vomiting, diarrhea, and other gastrointestinal side effects. ${ }^{41}$ Ganciclovir works in a similar manner as acyclovir. Though it has fewer side effects, it can cause blurred vision, punctuate keratitis, and eye irritation. ${ }^{8,42,43}$ Nonetheless, long-term treatment with these nucleoside analogs has resulted in resistance, especially in immunocompromised hosts, due to mutations in thymidine kinase or in DNA polymerase, which are selected for when the immune system does not efficiently remove newly made infectious virus. ${ }^{5,8,36,44-46}$ Second-line 
treatment includes foscarnet and cidofovir, but they have less specificity for viral DNA and are more likely to have significant toxicity in patients. Early generation drugs, such as idoxuridine, iododeoxyuridine, vidarabine, and trifluridine, are no longer used, because of increased side-effect profile and low bioavailability. ${ }^{8,47}$

As alluded to earlier, current treatment for HSV does not provide a cure, but rather decreases duration of symptoms and helps maintain the virus in latency. Recurrence can still occur, despite treatment with antiviral drugs. In the HEDS study, oral administration of $400 \mathrm{mg}$ of acyclovir decreased ocular HSV1 diseases by $45 \%$ (32\% placebo vs $19 \%$ acyclovir). ${ }^{48}$ In another study, recurrence of ocular HSV diseases was $23.1 \%$ in patients taking acyclovir. ${ }^{49}$ Risk of recurrence is $20 \%$ by 2 years, $40 \%$ by 5 years, and $67 \%$ by 7 years, and the risk increases with subsequent episodes. It should be stressed that acyclovir does not prevent SK, as the pathogenesis of SK is immunomediated, though by reducing viral load it can reduce the magnitude of the inflammatory response. Topical steroids help reduce progression of stromal inflammation, but they do not decrease epithelial disease. ${ }^{7}$ A quick summary of current treatment for different subtypes can be found in Table 1.

Relapsing and recurring stromal and endothelial diseases significantly increase the risk of corneal scarring from fibrosis and neovascularisation. ${ }^{4,7,8,11}$ Reactivation can be attributed to stress, trauma, and ultraviolet radiation. ${ }^{51,52}$ Endothelial keratitis due to recurrent infections can cause cell loss, permanent swelling, corneal scarring, opacities, tissue damage, and irregular astigmatism. ${ }^{53,54}$ As the number of episodes increases, corneal sensitivity to mechanical stimulation decreases. $^{53}$

Stromal infections are immunomediated and are the leading cause of corneal blindness in developed countries. They occur as a result of chronic viral reactivation, and lead to neurotrophic keratitis, a degenerative condition. A normal cornea is densely innervated, but lacks blood vessels. Subsequent episodes not only damage nerves, leading to decreased corneal sensation (corneal hypoesthesia), but also lead to angiogenesis, and neovascularization. ${ }^{53,54}$ Decreased

Table I Summary of current treatment for different subtypes

\begin{tabular}{ll}
\hline Subgroup & Treatment \\
\hline Epithelial subtype & Antiviral agents ${ }^{13}$ \\
Stromal subtype & $\begin{array}{l}\text { Combination of topical corticosteroids } \\
\text { and antiviral agents }\end{array}$ \\
Endothelial subtype & Combination of topical corticosteroids \\
& and antiviral agents \\
\hline
\end{tabular}

corneal sensation leads to loss of the corneal blink reflex. ${ }^{54}$ This immunomediated reaction occurs as a result of cytokines released by $\mathrm{CD}^{+} \mathrm{T}$ cells. ${ }^{55-57}$ While recurrent episodes of HSK can lead to stromal opacification, long-term use of antiviral drugs to prevent future episodes can increase the risk of resistance and toxicity. ${ }^{5,6,11}$ Since stromal response is immunomediated, steroids can help decrease recurrence, but they do not eliminate the virus. ${ }^{8,58}$

Additional changes due to HSK include changes in corneal thickness. In a study conducted by Wilhelmus et al, corneal thickness of disciform SK decreased 15\% (95\% confidence interval 10\%-20\%). ${ }^{59}$ Other complications include necrotizing SK, where ulceration and necrosis of the cornea are visible on slit-lamp examination. ${ }^{56,60}$ Keratitis has also been shown to cause dryness in patients with stromal infection. ${ }^{53}$

Each subsequent episode increases the patient's risk of developing corneal scaring and blindness. As current treatment helps maintain latency and only shortens the course of the disease, all infected patients are at risk of reactivation. Corneal scarring that leads to blindness is an indication for corneal transplantation. However, transplantation is complicated by increased risk of graft rejection in patients with HSK. ${ }^{10}$

\section{Conclusion}

HSK is an infection of the cornea caused by HSV. Primary infection is the result of direct exposure of the host's mucous membranes to infectious HSV. Following primary infection and the establishment of latency in the sensory ganglia, the virus can be stimulated to enter an infectious cycle, from which it returns to the cornea. Once there, this recurrent infection can cause various complications, in particular an inflammatory response, which if strong enough can compromise the integrity of the cornea, leading to corneal scarring and in severe cases blindness.

HSK is primarily a clinical diagnosis based on the findings of the split-lamp examination. Dendritiform epithelial lesions on slit-lamp examination are pathognomonic for keratitis. However, previous studies have shown that ocular lesions caused by cytomegalovirus, herpes zoster, adenovirus, and fungal infections have been misdiagnosed as HSK lesions. ${ }^{7,10,11}$ Other diagnostic tests, such as PCR assay, ELISA, IFA, and viral cultures, have provided a more definitive diagnosis, but have their own limitations. Additionally, variation in different subtypes of keratitis has made diagnosis of atypical lesions more difficult.

Accurate and prompt diagnosis is necessary to aid the physician to know which treatment will have the best 
outcomes and thus prevent further complications. Latency of HSV has prevented pharmacotherapy from eliminating the virus. Current pharmacotherapy treatments have helped decrease recurrence and maintain latency, but secondary infections can still occur. ${ }^{23,24}$ Recurring lesions increase a patient's risk of developing fibrosis, scarring, and neovascularization of the cornea. SK, an immunomodulated response, is the major cause of decreased corneal sensation and blindness. Acyclovir is not effective against the inflammatory stage of SK, as there is little virus to be found during peak inflammation. It should be noted that each episode of recurrent infection increases the risk of subsequent episodes and further complicates clinical management. ${ }^{4}$

\section{Acknowledgments}

This work was supported by National Institutes of Health grants EY16352 (PMS) and EY21247 (PMS) and an unrestricted grant from Research to Prevent Blindness to the Department of Ophthalmology, Saint Louis University.

\section{Disclosure}

The authors report no conflicts of interest in this work.

\section{References}

1. Pinninti SG, Kimberlin DW. Neonatal herpes simplex virus infections. Pediatr Clin North Am. 2013;60(2):351-365.

2. Kimberlin DW, Lin CY, Jacobs RF, et al. Natural history of neonatal herpes simplex virus infections in the acyclovir era. Pediatrics. 2001; 108(2):223-229.

3. Langenberg AG, Corey L, Ashley RL, Leong WP, Straus SE. Chiron HSV Vaccine Study Group A prospective study of new infections with herpes simplex virus type 1 and type 2. N Engl J Med. 1999; 341(19):1432-1438.

4. Darougar S, Wishart MS, Viswalingam ND. Epidemiological and clinical features of primary herpes simplex virus ocular infection. Br J Ophthalmol. 1985;69(1):2-6.

5. Farooq AV, Shukla D. Herpes simplex epithelial and stromal keratitis: an epidemiologic update. Surv Ophthalmol. 2012;57(5):448-462.

6. Lairson DR, Begley CE, Reynolds TF, Wilhelmus KR. Prevention of herpes simplex virus eye disease: a cost-effectiveness analysis. Arch Ophthalmol. 2003;121(1):108-112.

7. Liesegang TJ. Herpes simplex virus epidemiology and ocular importance. Cornea. 2001;20(1):1-13.

8. Tsatsos M, MacGregor C, Athanasiadis I, Moschos MM, Hossain P, Anderson D. Herpes simplex virus keratitis: an update of the pathogenesis and current treatment with oral and topical antiviral agents. Clin Exp Ophthalmol. Epub 2016 Jun 8.

9. Souza PM, Holland EJ, Huang AJ. Bilateral herpetic keratoconjunctivitis. Ophthalmology. 2003;110(3):493-496.

10. McGilligan VE, Moore JE, Tallouzi M, et al. A comparison of the clinical and molecular diagnosis of herpes simplex keratitis. Open $J$ Ophthalmol. 2014;4(3):65-74.

11. Liesegang TJ, Melton LJ, Daly PJ, Daly PJ, Ilstrup DM. Epidemiology of ocular herpes simplex: incidence in Rochester, Minn, 1950 through 1982. Arch Ophthalmol. 1989;107(8):1155-1159.

12. LaVail JH, Tauscher AN, Hicks JW, Harrabi O, Melroe GT, Knipe DM. Genetic and molecular in vivo analysis of herpes simplex virus assembly in murine visual system neurons. $J$ Virol. 2005;79(17):11142-11150.
13. Wilhelmus KR. Antiviral treatment and other therapeutic interventions for herpes simplex virus epithelial keratitis. Cochrane Database Syst Rev. 2015;1:CD002898.

14. Sears AE, Roizman B. Amplification by host cell factors of a sequence contained within the herpes simplex virus 1 genome. Proc Natl Acad Sci U S A. 1990;87(23):9441-9444.

15. Shoji J, Sakimoto T, Inada N, et al. A diagnostic method for herpes simplex keratitis by simultaneous measurement of viral DNA and virus-specific secretory IgA in tears: an evaluation. Jpn J Opthalmol. 2016;60(4):294-301.

16. Chang EJ, Dreyer EB. Herpesvirus infections of the anterior segment. Int Ophthalmol Clin. 1996;36(3):17-28.

17. Green LK, Pavan-Langston D. Herpes simplex ocular inflammatory disease. Int Ophthalmol Clin. 2006;46(2):27-37.

18. Edelhauser HF, Schultz RO, Van Horn DL. Experimental herpes simplex keratitis: corneal hydration, electrolyte content and structural changes. Am J Ophthalmol. 1969;68(3):458-466.

19. Van Home DL, Edelhauser HF, Schultz RO. Experimental herpes simplex keratitis: early alteration of corneal epithelium and stroma. Arch Ophthalmol. 1970;84(1):67-75.

20. Reidy JJ. 2011-2012 Basic and Clinical Science Course - Section 8: External Disease and Cornea. San Francisco: American Academy of Ophthalmology; 2011.

21. Koizumi N, Nishida K, Adachi W, et al. Detection of herpes simplex virus DNA in atypical epithelial keratitis using polymerase chain reaction. Br J Ophthalmol. 1999;83(8):957-960.

22. El-Aal AM, El Sayed M, Mohammed E, Ahmed M, Fathy M. Evaluation of herpes simplex detection in corneal scrapings by three molecular methods. Curr Microbiol. 2006;52(5):379-382.

23. Satpathy G, Mishra AK, Tandon R, et al. Evaluation of tear samples for herpes simplex virus 1 (HSV) detection in suspected cases of viral keratitis using PCR assay and conventional laboratory diagnostic tools. Br J Ophthalmol. 2011;95(3):415-418.

24. Kaye S, Choudhary A. Herpes simplex keratitis. Prog Retin Eye Res. 2006;25(4):355-380.

25. Mayers-Elliot R, Pettit T, Maxwell W. Viral antigens in the immune ring of herpes simplex stromal keratitis. Arch Ophthalmol. 1980; 98(5):897-904.

26. Olsen TW, Hardten DR, Meiusi RS, Holland EJ. Linear endotheliitis. Am J Opthalmol. 1994;117(4):468-474.

27. Knickelbein JE, Hendricks RL, Charukamnoetkanok P. Management of herpes simplex virus stromal keratitis: an evidence-based review. Surv Ophthalmol. 2009;54(2):226-234.

28. Kowalski RP, Gordon YJ, Romanowski EG, Araullo-Cruz T, Kinchington PR. A comparison of enzyme immunoassay and polymerase chain reaction with the clinical examination for diagnosing ocular herpetic disease. Ophthalmology. 1993;100(4):530-533.

29. Rübben A, Baron JM, Grussendorf-Conen EI. Routine detection of herpes simplex virus and varicella zoster virus by polymerase chain reaction reveals that initial herpes zoster is frequently misdiagnosed as herpes simplex. Br J Dermatol. 1997;137(2):259-261.

30. Marangon FB, Miller D, Alfonso E. Laboratory results in ocular viral diseases: implications in clinical-laboratory correlation. Arq Bras Oftalmol. 2007;70(2):189-194.

31. Wald A, Corey L, Cone R, Hobson A, Davis G, Zeh J. Frequent genital herpes simplex virus 2 shedding in immunocompetent women: effect of acyclovir treatment. J Clin Invest. 1997;99(5):1092-1097.

32. Sharma S, Das D, Anand R, Das T, Kannabiran C. Reliability of nested PCR in the diagnosis of bacterial endophthalmitis. Am J Ophthalmol. 2002;133(1):142-144.

33. Goldschmidt P, Rostane H, Saint-Jean C, et al. Effects of topical anaesthetics and fluorescein on the real-time PCR used for the diagnosis of herpesviruses and Acanthamoeba keratitis. Br J Ophthalmol. 2006; 90(11):1354-1356.

34. Seitzman GD, Cevallos V, Margolis TP. Rose bengal and lissamine green inhibit detection of herpes simplex virus by PCR. Am J Ophthalmol. 2006;141(4):756-758. 
35. Madhavan HN, Priya K, Anand AR, Therese KL. Detection of herpes simplex (HSV) genome using polymerase chain reaction (PCR) in clinical samples comparison of PCR with standard laboratory methods for detection of HSV. J Clin Virol. 1999;14(2):145-151.

36. Vadlapudi AD, Vadlapatla RK, Mitra AK. Update on emerging antivirals for the management of herpes simplex virus infections: a patenting perspective. Recent Pat Antiinfect Drug Discov. 2013;8(1):55-67.

37. Tyring SK, Baker D, Snowden W. Valacyclovir for herpes simplex virus infection: long-term safety and sustained efficacy after 20 years' experience with acyclovir. J Infect Dis. 2002;186(Suppl 1):S40-S46.

38. Lisco A, Vanpouille C, Tchesnokov EP, et al. Acyclovir is activated into a HIV-1 reverse transcriptase inhibitor in herpesvirus-infected human tissues. Cell Host Microbe. 2008;4(3):260-270.

39. De Miranda P, Blum MR. Pharmacokinetics of acyclovir after intravenous and oral administration. J Antimicrob Chemother. 1983; 12 Suppl B:29-37.

40. Wagstaff AJ, Faulds D, Goa KL. Aciclovir: a reappraisal of its antiviral activity, pharmacokinetic properties and therapeutic efficacy. Drugs. 1994;47(1):153-205.

41. Perry CM, Faulds D. Valaciclovir: a review of its antiviral activity, pharmacokinetic properties, and therapeutic efficacy in herpesvirus infections. Drugs. 1996;52(5):754-771.

42. Kaufman HE, Haw WH. Ganciclovir ophthalmic gel $0.15 \%$ : safety and efficacy of a new treatment for herpes simplex keratitis. Curr Eye Res. 2012;37(7):654-660.

43. Colin J, Hoh HB, Easty DL, et al. Ganciclovir ophthalmic gel (Virgan; $0.15 \%$ ) in the treatment of herpes simplex keratitis. Cornea. 1997; 16(4):393-399.

44. Kudo E, Shiota H, Naito T, Satake K, Itakura M. Polymorphisms of thymidine kinase gene in herpes simplex virus type 1: analysis of clinical isolates from herpetic keratitis patients and laboratory strains. $J$ Med Virol. 1998;56(2):151-158.

45. Piret J, Boivin G. Resistance of herpes simplex viruses to nucleoside analogues: mechanisms, prevalence, and management. Antimicrob Agents Chemother. 2011;55(2):459-472.

46. Sauerbrei A, Deinhardt S, Zell R, Wutzler P. Testing of herpes simplex virus for resistance to antiviral drugs. Virulence. 2010;1(6):555-557.

47. Morfin F, Thouvenot D. Herpes simplex virus resistance to antiviral drugs. J Clin Virol. 2003;26(1):29-37.
48. Wilhelmus KR, Beck RW, Moke PS, et al. Acyclovir for the prevention of recurrent herpes simplex virus eye disease. $N$ Engl J Med. 1998; 339(5):300-306.

49. Miserocchi E, Modorati G, Galli L, Rama P. Efficacy of valacyclovir vs acyclovir for the prevention of recurrent herpes simplex virus eye disease: a pilot study. Am J Ophthalmol. 2007;144(4):547-551.

50. Hill GM, Ku ES, Dwarakanathan S. Herpes simplex keratitis. Dis Mon. 2014;60(6):239-246.

51. [No authors listed]. Psychological stress and other potential triggers for recurrences of herpes simplex virus eye infections. Arch Ophthalmol. 2001;118(12):1617-1625.

52. [No authors listed]. Predictors of recurrent herpes simplex virus keratitis. Cornea. 2001;20(2):123-128.

53. Gallar J, Tervo TM, Neira W. Selective changes in human corneal sensation associated with herpes simplex virus keratitis. Invest Ophthalmol Vis Sci. 2010;51(9):4516-4522.

54. Hamrah P, Cruzat A, Dastjerdi MH, et al. Corneal sensation and subbasal nerve alterations in patients with herpes simplex keratitis: an in vivo confocal microscopy study. Ophthalmology. 2010;117(10):1930-1936.

55. Al-Dujaili LJ, Clerkin PP, Clement C, et al. Ocular herpes simplex virus how are latency, reactivation, recurrent disease and therapy interrelated? Future Microbiol. 2011;6(8):877-907.

56. Tang Q, Chen W, Hendricks RL. Proinflammatory functions of IL-2 in herpes simplex virus corneal infection. J Immunol. 1997;158(3): $1275-1283$.

57. Tang Q, Hendricks RL. Interferon $\gamma$ regulates platelet endothelial cell adhesion molecule 1 expression and neutrophil infiltration into herpes simplex virus-infected mouse corneas. J Exp Med. 1996;184(4): 1435-1447.

58. Wilhelmus KR, Gee L, Hauck WW, et al. Herpetic Eye Disease Study: a controlled trial of topical corticosteroids for herpes simplex stromal keratitis. Ophthalmology. 1994;101(12):1883-1896.

59. Wilhelmus KR, Sugar J, Hyndiuk RA, Stulting RD. Corneal thickness changes during herpes simplex virus disciform keratitis. Cornea. 2004; 23(2):154-157.

60. Holland EJ, Schwartz GS. Classification of herpes simplex virus keratitis. Cornea. 1999;18(2):144-154.
Clinical Ophthalmology

\section{Publish your work in this journal}

Clinical Ophthalmology is an international, peer-reviewed journal covering all subspecialties within ophthalmology. Key topics include: Optometry; Visual science; Pharmacology and drug therapy in eye diseases; Basic Sciences; Primary and Secondary eye care; Patient Safety and Quality of Care Improvements. This journal is indexed on

\section{Dovepress}

PubMed Central and CAS, and is the official journal of The Society of Clinical Ophthalmology (SCO). The manuscript management system is completely online and includes a very quick and fair peer-review system, which is all easy to use. Visit http://www.dovepress.com/ testimonials.php to read real quotes from published authors. 